\title{
River-Stage Data, Colorado River, Glen Canyon Dam To Upper Lake Mead, Arizona, 1990-94 By R.W. GAUGER
}

U.S. GEOLOGICAL SURVEY

Open-File Report 96-626

Prepared in cooperation with the BUREAU OF RECLAMATION

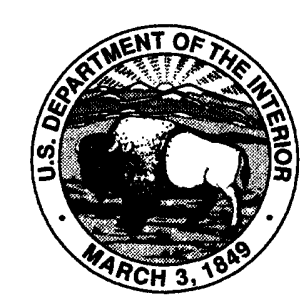




\title{
U.S. DEPARTMENT OF THE INTERIOR BRUCE BABBITT, Secretary
}

\author{
U.S. GEOLOGICAL SURVEY \\ Gordon P. Eaton, Director
}

Any use of trade, product, or firm names in this publication is for descriptive purposes only and does not constitute endorsement by the U.S. Government.

For additional information write to:

District Chief

U.S. Geological Survey

Water Resources Division

375 South Euclid Avenue

Tucson, AZ 85719-6644
Copies of this report can be purchased from:

U.S. Geological Survey

Branch of Information Services

Box 25286,

Denver, CO 80225-0286 


\section{CONTENTS}

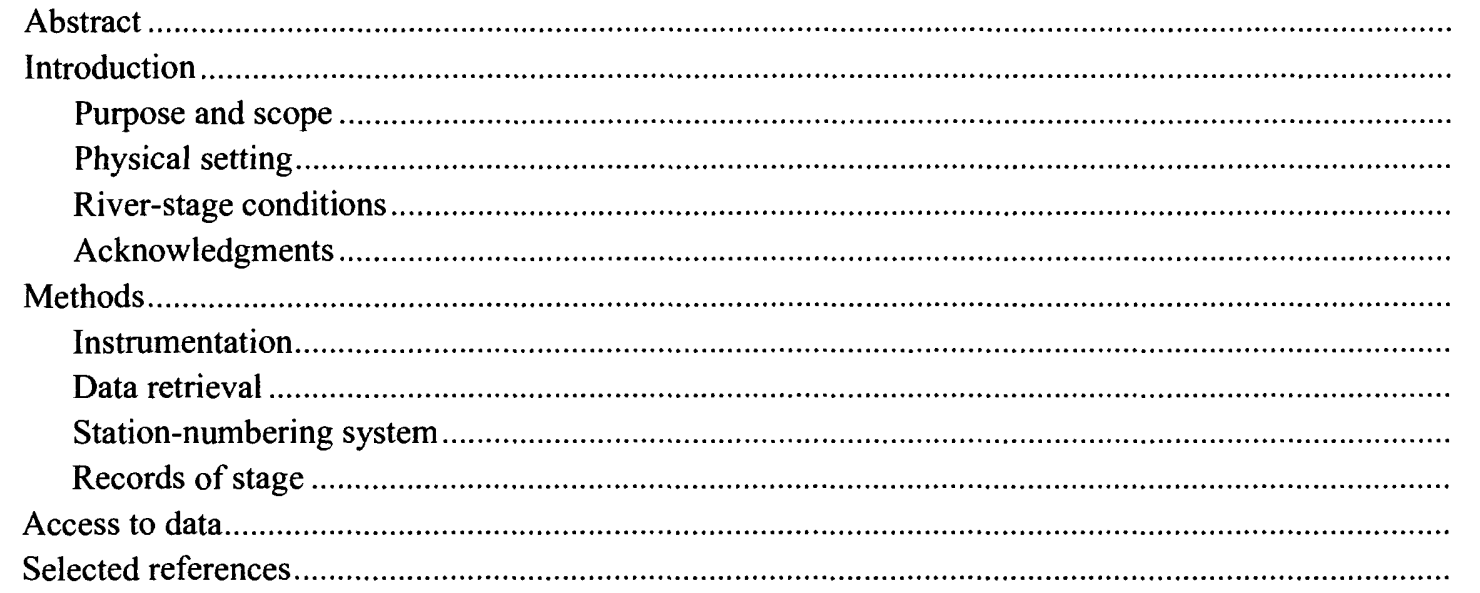

Abstract
Introduction
Purpose and scope
Physical setting
River-stage conditions
Acknowledgments
Methods
Instrumentation
Station-numbering system to data
Selected references.

\section{FIGURES}

1. Map showing study area and locations of stage-gaging stations and continuous-record streamflow-gaging stations, Colorado River, Glen Canyon Dam to upper Lake Mead,

Arizona

2. Cross sections at selected stage-gaging stations

3. Graph showing stage of Colorado River at river miles 45 and 170.

4. Diagram of research flows, June 1990 to July 1991

5-9. Graphs showing:

5. Discharges at streamflow-gaging station, Colorado River at Lees Ferry, Arizona, during research-flow period 1990-91

6. Comparison of stage of Colorado River at river miles 55 and 70 to inflow from the Little Colorado River at river mile 61.5, January 1993:
A. Stage at river miles 55 and 70
B. Inflow from the Little Colorado River.
7. Comparison of stage of Colorado River at river miles 55 and 70 to show the response of stage to inflow of water and debris flows from ungaged tributary canyons,

August 1993

8. Comparison of stage of Colorado River at river miles 80 and 90 to inflow from Bright Angel Creek at river mile 88, August 1992:
A. Stage at river miles 80 and 90
B. Inflow from Bright Angel Creek
9. Comparison of stage of Colorado River at river miles 145 and 160 to inflow from Havasu Creek at river mile 157, August 1993:
A. Stage at river miles 145 and 160
B. Inflow from Havasu Creek

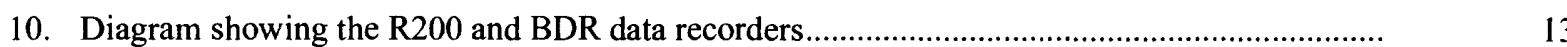

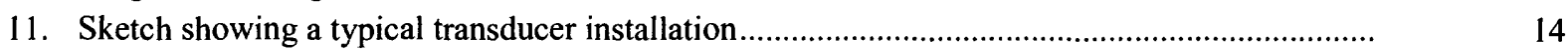

12-13. Graphs showing:

12. Comparison of stage of Colorado River upstream and downstream from Granite Rapid.....

13. River stage data, Colorado River, Glen Canyon Dam to upper Lake Mead, Arizona, October 1990 through July 1993 


\section{TABLES}

1. Station numbers and site names, Colorado River, Glen Canyon Dam

to upper Lake Mead, Arizona, 1990-94.

2. Sample data table in standard B-card format

\section{CONVERSION FACTORS}

\begin{tabular}{rrll}
\hline Multiply & By & To obtain \\
\hline inch (in.) & 25.4 & millimeter \\
foot $(\mathrm{ft})$ & 0.3048 & meter \\
mile $(\mathrm{mi})$ & 1.609 & kilometer \\
cubic foot per second $\left(\mathrm{ft}^{3} / \mathrm{s}\right)$ & 0.02832 & cubic meter per second \\
pound & 0.4535 & kilogram \\
square miles $\left(\mathrm{mi}^{2}\right)$ & 2.590 & square kilometers \\
\hline
\end{tabular}

\section{VERTICAL DATUM}

Sea level: In this report, "sea level" refers to the National Geodetic Vertical Datum of 1929 - a geodetic datum derived from a general adjustment of the first-order level nets of the United States and Canada, formerly called Sea Level Datum of 1929. 


\title{
River-Stage Data, Colorado River, Glen Canyon Dam To Upper Lake Mead, Arizona, 1990-94
}

\author{
By R.W. Gauger
}

\begin{abstract}
The U.S. Geological Survey collected river-stage data at 53 temporary gaging stations along the Colorado River downstream from Glen Canyon Dam to upper Lake Mead during 1990 to 1994. These data were collected to support research scientists in their investigations as part of the Bureau of Reclamation's Glen Canyon Environmental Studies. The data-collection period included about 14 months of dam releases designed for research purposes from June 1990 to July 1991. Data graphs show travel times of the daily discharge waves between selected sites for selected periods. Graphs also show effects of storm runoff from tributary canyons on river stage. The data are available in electronic form from the District Chief, U.S. Geological Survey, Tucson, Arizona.
\end{abstract}

\section{INTRODUCTION}

In 1983, the U.S. Geological Survey (USGS) began an intensive program of collecting streamflow and sediment data on the Colorado River as part of Phase I of the Glen Canyon Environmental Studies (GCES), an interagency study, in cooperation with the Bureau of Reclamation (BOR). The goal of GCES Phase I was to determine whether releases from Glen Canyon Dam were adversely affecting the environmental and recreational resources along the Colorado River in Grand Canyon National Park and to determine whether alternative methods of releasing water could protect or enhance those resources. Data collection during Phase I of the GCES program, which ended in 1986, was affected by high flows in 1983, 1984, 1985, and 1986 that prevented adequate study of flows typical of the dam's normal operating criteria (Bureau of Reclamation, 1988).

After a review of Phase I by the National Research Council (National Research Council, 1987), the Secretary of the Interior directed that further studies be conducted. Phase II of the GCES program began in 1990 with the purpose of collecting additional physical, chemical, and biological information. The USGS, in cooperation with the BOR, began to collect river-stage data in 1990. Stage-gaging stations were installed at 53 locations spaced approximately $5 \mathrm{mi}$ apart from 4.5 mi downstream from Glen Canyon Dam to upper Lake Mead (fig. 1 and table 1). The data-collection network was designed for testing of a one-dimensional discharge-routing model for the Colorado River from Glen Canyon Dam to Diamond Creek (Wiele and Smith, 1996). Data also have been used to calculate hydrographs for GCES study sites that are not located at gaging stations (Griffin and Wiele, 1996) and to estimate inflow from tributaries (S.M. Wiele, hydrologist, U.S. Geological Survey, written commun., 1996). The data are available in electronic form from the District Chief, U.S. Geological Survey, Tucson, Arizona.

\section{Purpose and Scope}

The purpose of this report is to present portions of the river-stage data for the Colorado River downstream from Glen Canyon Dam to upper 


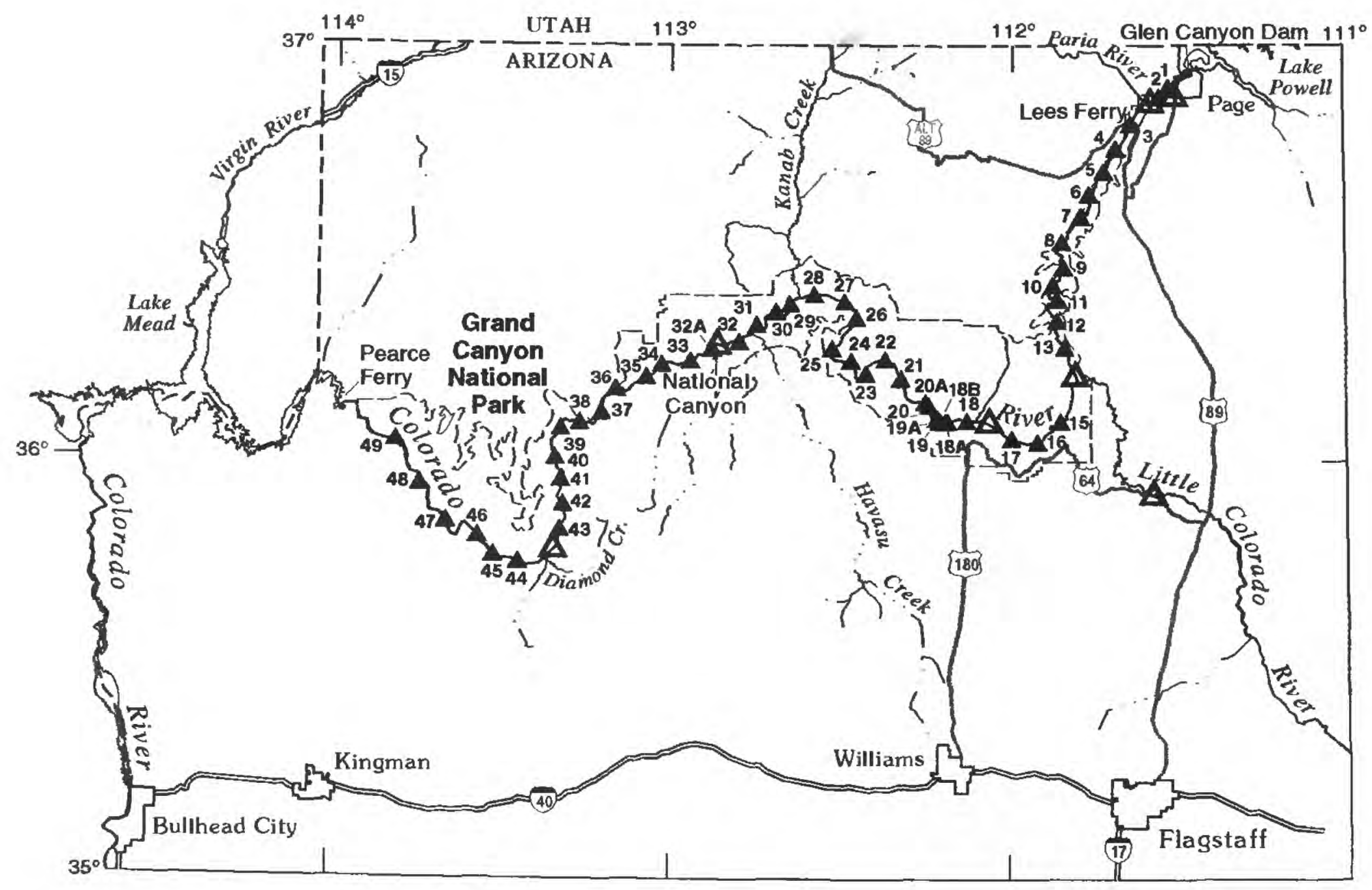

Base from U.S. Geological Survey

digital data, t: $100,000,1980$

Lambert Conformal Conic projection

Standard parallels $29^{\circ} 30^{\circ}$ and $45^{\circ} 30^{\prime}$,

central meridian $-96^{\circ} 00^{\circ}$
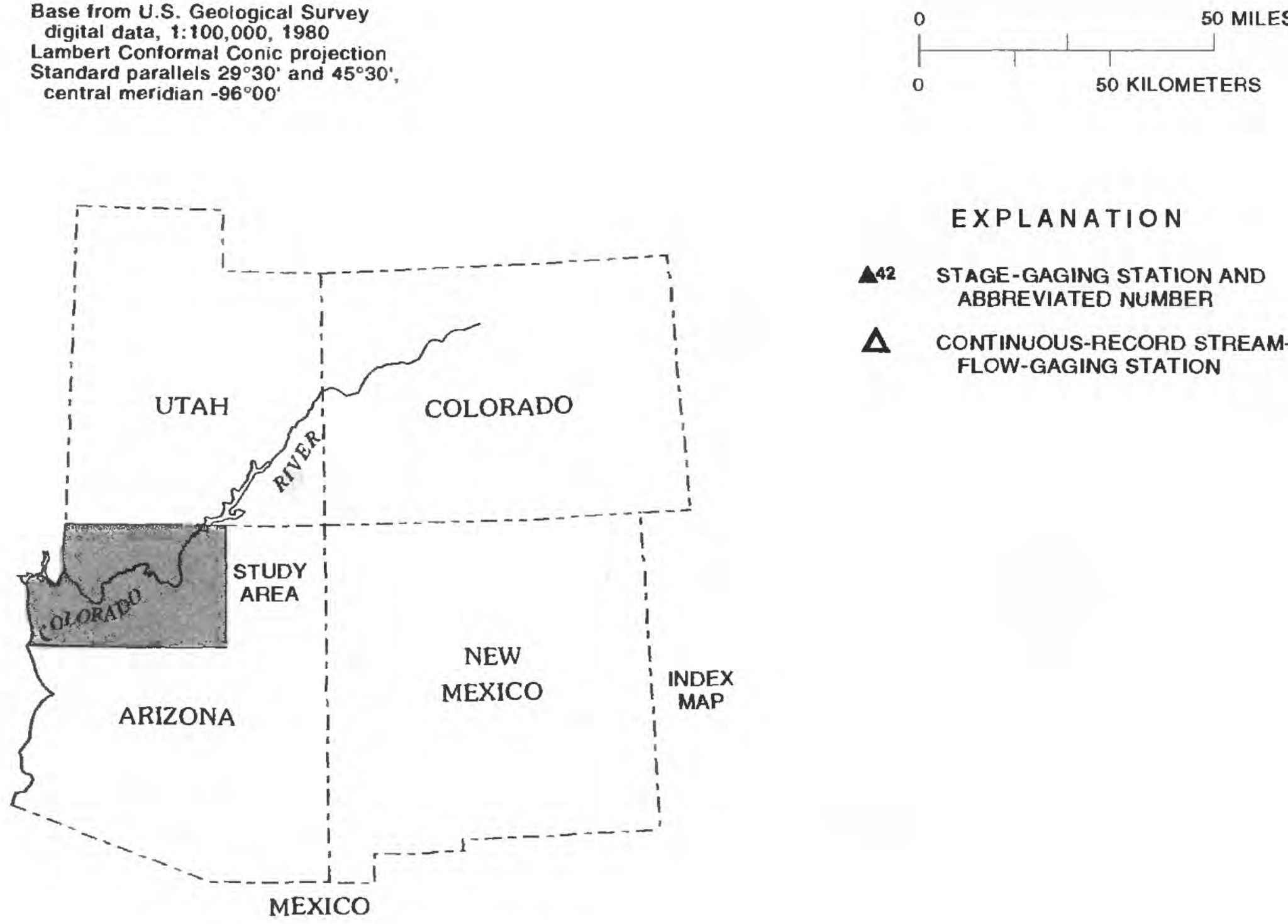

EXPLANATION

$\triangle 42$ STAGE-GAGING STATION AND ABBREVIATED NUMBER

$\triangle$ CONTINUOUS-RECORD STREAMFLOW-GAGING STATION

Figure 1. Study area and locations of stage-gaging stations and continuous-record streamflow-gaging stations, Colorado River, Glen Canyon Dam to upper Lake Mead, Arizona. 
Table 1. Station numbers and site names, Colorado River, Glen Canyon Dam to upper Lake Mead, Arizona, 1990-94

[RM, river mile. All stations are downstream from Lees Ferry, Arizona, in Grand Canyon National Park except stations 09379950 and 09379965 , which are in Glen Canyon National Recreation Area]

\begin{tabular}{|c|c|c|c|c|}
\hline $\begin{array}{l}\text { Station } \\
\text { number }\end{array}$ & Latitude & Longitude & Site name & Site description \\
\hline 09379950 & $36^{\circ} 53^{\prime} 50^{\prime \prime}$ & $111^{\circ} 31^{\prime 2} 26^{\prime \prime}$ & R200-01 & 11 miles above Lees Ferry \\
\hline 09379965 & $36^{\circ} 52^{\prime 2} 26^{\prime \prime}$ & $111^{\circ} 33^{\prime} 07^{\prime \prime}$ & $\mathrm{R} 200-02$ & 6.5 miles above Lees Ferry \\
\hline 09383003 & $36^{\circ} 48^{\prime 2} 28^{\prime \prime}$ & $111^{\circ} 38^{\prime} 09^{\prime \prime}$ & R200-03 & At RM 5 below 5 Mile Wash \\
\hline 09383006 & $36^{\circ} 44^{\prime} 56^{\prime \prime}$ & $111^{\circ} 40^{\prime} 53^{\prime \prime}$ & R200-04 & At RM 10 below 10 Mile Rock \\
\hline 09383009 & $36^{\circ} 41^{\prime} 39^{\prime \prime}$ & $111^{\circ} 43^{\prime} 02^{\prime \prime}$ & $\mathrm{R} 200-05$ & At RM 15 below Sheer Wali Rapid \\
\hline 09383035 & $36^{\circ} 38^{\prime} 15^{\prime \prime}$ & $111^{\circ} 45^{\prime} 39^{\prime \prime}$ & R200-06 & At RM 20 above North Canyon Rapid \\
\hline 09383040 & $36^{\circ} 35^{\prime} 03^{\prime \prime}$ & $111^{\circ} 47^{\prime} 02^{\prime \prime}$ & R200-07 & At RM 25 below 24 Mile Rapid \\
\hline 09383050 & $36^{\circ} 31^{\prime} 24^{\prime \prime}$ & $111^{\circ} 50^{\prime} 33^{\prime \prime}$ & R200-08 & At RM 30 below 29 Mile Rapid \\
\hline 09383060 & $36^{\circ} 27^{\prime} 42^{\prime \prime}$ & $111^{\circ} 50^{\prime} 14^{\prime \prime}$ & $\mathrm{R} 200-09$ & At RM 35 below Nautiloid Canyon \\
\hline 09383070 & $36^{\circ} 25^{\prime} 10^{\prime \prime}$ & $111^{\circ} 52^{\prime} 08^{\prime \prime}$ & $\mathrm{R} 200-10$ & At RM 40 at tramway site \\
\hline 09383075 & $36^{\circ} 23^{\prime} 06^{\prime \prime}$ & $111^{\circ} 51^{\circ} 24^{\prime \prime}$ & R200-11 & At RM 45 below President Harding Rapid \\
\hline 09383080 & $36^{\circ} 20^{\prime} 04^{\prime \prime}$ & $111^{\circ} 51^{\prime} 34^{\prime \prime}$ & $\mathrm{R} 200-12$ & At RM 50 below 50 Mile Camp \\
\hline 09383090 & $36^{\circ} 16^{\prime} 20^{\prime \prime}$ & $111^{\circ} 50^{\prime} 10^{\prime \prime}$ & R200-13 & At RM 55 above Kwagunt Rapid \\
\hline 09402390 & $36^{\circ} 05^{\prime} 42^{\prime \prime}$ & $111^{\circ} 50^{\prime} 51^{\prime \prime}$ & $\mathrm{R} 200-15$ & At RM 70 below Basalt Canyon \\
\hline 09402430 & $36^{\circ} 02^{\prime} 41^{\prime \prime}$ & $111^{\circ} 54^{\prime} 55^{\prime \prime}$ & $\mathrm{R} 200-16$ & At RM 76 above Hance Rapid \\
\hline 09402460 & $36^{\circ} 03^{\prime} 14^{\prime \prime}$ & $111^{\circ} 59^{\prime} 30^{\prime \prime}$ & R200-17 & At RM 80 above Grapevine Rapid \\
\hline 09403020 & $36^{\circ} 05^{\prime} 46^{\prime \prime}$ & $112^{\circ} 07^{\prime} 26^{\prime \prime}$ & $\mathrm{R} 200-18$ & At RM 90 above Horn Creek Rapid \\
\hline 09403030 & $36^{\circ} 05^{\prime} 51^{\prime \prime}$ & $112^{\circ} 10^{\prime} 53^{\prime \prime}$ & R200-18A & At RM 93 above Granite Rapid \\
\hline 09403035 & $36^{\circ} 05^{\prime} 52^{\prime \prime}$ & $112^{\circ} 11^{\prime} 19^{\prime \prime}$ & $\mathrm{R} 200-18 \mathrm{~B}$ & At RM 93.5 below Granite Rapid \\
\hline 09403040 & $36^{\circ} 05^{\prime} 55^{\prime \prime}$ & $112^{\circ} 12^{\prime} 19^{\prime \prime}$ & R200-19 & At RM 95 above Hermit Rapid \\
\hline 09403045 & $36^{\circ} 06^{\circ} 03^{\prime \prime}$ & $112^{\circ} 12^{\prime} 48^{\prime \prime}$ & R200-19A & At RM 95.5 below Hermit Rapid \\
\hline 09403060 & $36^{\circ} 08^{\prime} 02^{\prime \prime}$ & $112^{\circ} 14^{\prime} 33^{\prime \prime}$ & $\mathrm{R} 200-20$ & At RM 98 above Crystal Rapid \\
\hline 09403065 & $36^{\circ} 08^{\prime} 20^{\prime \prime}$ & $112^{\circ} 14^{\prime} 52^{\prime \prime}$ & $\mathrm{R} 200-20 \mathrm{~A}$ & At RM 98.5 below Crystal Rapid \\
\hline 09403100 & $36^{\circ} 11^{\prime} 49^{\prime \prime}$ & $112^{\circ} 19^{\prime} 14^{\prime \prime}$ & $\mathrm{R} 200-21$ & At RM 105 below Ruby Rapid \\
\hline 09403150 & $36^{\circ} 14^{\prime} 31^{\prime \prime}$ & $112^{\circ} 22^{\prime} 02^{\prime \prime}$ & R200-22 & At RM 110 below 110 Mile Rapid \\
\hline 09403170 & $36^{\circ} 12^{\prime} 31^{\prime \prime}$ & $112^{\circ} 25^{\prime} 25^{\prime \prime}$ & $\mathrm{R} 200-23$ & At RM 115 below Garnet Canyon \\
\hline 09403200 & $36^{\circ} 14^{\prime} 20^{\prime \prime}$ & $112^{\circ} 28^{\prime} 07^{\prime \prime}$ & R200-24 & At RM 120 above Blacktaii Rapid \\
\hline 09403250 & $36^{\circ} 16^{\prime} 09^{\prime \prime}$ & $1 \mathrm{i} 2^{\circ} 31^{\prime} 33^{\prime \prime}$ & $\mathrm{R} 200-25$ & At RM 125 above Fossil Rapid \\
\hline 09403300 & $36^{\circ} 20^{\prime} 33^{\prime \prime}$ & $112^{\circ} 27^{\prime} 15^{\prime \prime}$ & $\mathrm{R} 200-26$ & At RM 131 above Deubendorff Rapid \\
\hline 09403350 & $36^{\circ} 22^{\prime} 49^{\prime \prime}$ & $112^{\circ} 29^{\prime} 16^{\prime \prime}$ & $\mathrm{R} 200-27$ & At RM 135 at Granite Narrows \\
\hline 09403400 & $36^{\circ} 23^{\prime} 48^{\prime \prime}$ & $112^{\circ} 34^{\prime} 40^{\prime \prime}$ & R200-28 & At RM 140 below 140 Mile Canyon \\
\hline 09403860 & $36^{\circ} 22^{\prime} 29^{\prime \prime}$ & $112^{\circ} 38^{\prime} 57^{\prime \prime}$ & $\mathrm{R} 200-29$ & At RM 145 above Olo Canyon \\
\hline 09403870 & $36^{\circ} 21^{\prime} 14^{\prime \prime}$ & $112^{\circ} 41^{\prime 2} 4^{\prime \prime}$ & R200-30 & At RM 150 above Upset Rapid \\
\hline 09403880 & $36^{\circ} 19^{\prime} 32^{\prime \prime}$ & $112^{\circ} 45^{\prime} 04^{\prime \prime}$ & $\mathrm{R} 200-31$ & At RM 155 below Sinyala Rapid \\
\hline 09404117 & $36^{\circ} 17^{\prime} 05^{\prime \prime}$ & $112^{\circ} 48^{\prime} 06^{\prime \prime}$ & R200-32 & At RM 1603 miles below Havasu Creek \\
\hline 09404119 & $36^{\circ} 16^{\prime} 07^{\prime \prime}$ & $112^{\circ} 52^{\prime} 47^{\prime \prime}$ & R200-32A & At RM 165.5 above National Canyon \\
\hline 09404130 & $36^{\circ} 14^{\prime} 25^{\prime \prime}$ & $112^{\circ} 56^{\prime} 42^{\prime \prime}$ & R200-33 & At RM 170 above Stairway Canyon \\
\hline 09404135 & $36^{\circ} 13 ' 54^{\prime \prime}$ & $113^{\circ} 01^{\prime} 43^{\prime \prime}$ & R200-34 & At RM 175 below Cove Canyon \\
\hline 09404140 & $36^{\circ} 12^{\prime} 02^{\prime \prime}$ & $113^{\circ} 04^{\prime} 29^{\prime \prime}$ & R200-35 & At RM 179 above Lava Fails Rapid \\
\hline 09404145 & $36^{\circ} 10^{\prime} 17^{\prime \prime}$ & $113^{\circ} 09^{\prime} 48^{\prime \prime}$ & $\mathrm{R} 200-36$ & At RM 185 above 185 Mile Rapid \\
\hline 09404150 & $36^{\circ} 06^{\prime} 54^{\prime \prime}$ & $113^{\circ} 12^{\prime} 15^{\prime \prime}$ & R200-37 & At RM 1902 miles below Whitmore Rapid \\
\hline 09404155 & $36^{\circ} 05^{\prime} 34^{\prime \prime}$ & $113^{\circ} 16^{\prime} 12^{\prime \prime}$ & R200-38 & At RM 195 below 194 Mile Canyon \\
\hline 09404165 & $36^{\circ} 04^{\prime} 42^{\prime \prime}$ & $113^{\circ} 19^{\prime} 30^{\prime \prime}$ & $\mathrm{R} 200-39$ & At RM 200 below Parashant Wash \\
\hline 09404170 & $36^{\circ} 00^{\prime} 30^{\prime \prime}$ & $113^{\circ} 20^{\prime} 34^{\prime \prime}$ & R200-40 & At RM 205 above 205 Mile Rapid \\
\hline 09404180 & $35^{\circ} 57^{\prime} 22^{\prime \prime}$ & $113^{\circ} 19^{\prime} 30^{\prime \prime}$ & R200-41 & At RM 210 below Granite Park \\
\hline 09404185 & $35^{\circ} 53^{\prime} 46^{\prime \prime}$ & $113^{\circ} 19^{\prime} 03^{\prime \prime}$ & R200-42 & At RM 215 above Three Springs Canyon \\
\hline 09404190 & $35^{\circ} 50^{\prime} 06^{\prime \prime}$ & $113^{\circ} 19^{\prime} 33^{\prime \prime}$ & $\mathrm{R} 200-43$ & At RM 220 above 220 Mile Canyon \\
\hline 09404210 & $35^{\circ} 45^{\prime} 25^{\prime \prime}$ & $113^{\circ} 26^{\prime} 57^{\prime \prime}$ & R200-44 & At RM 231 below Travertine Falls \\
\hline 09404215 & $35^{\circ} 46^{\prime} 22^{\prime \prime}$ & $113^{\circ} 31^{\prime} 17^{\prime \prime}$ & R200-45 & At RM 235 above Bridge Canyon Rapid \\
\hline 09404217 & $35^{\circ} 49^{\prime} 08^{\prime \prime}$ & $113^{\circ} 34^{\prime} 04^{\prime \prime}$ & R200-46 & At RM 239 above Separation Canyon \\
\hline 09404230 & $35^{\circ} 51^{\prime} 19^{\prime \prime}$ & $113^{\circ} 39^{\prime} 47^{\prime \prime}$ & R200-47 & At RM 249 near Surprise Canyon \\
\hline 09404235 & $35^{\circ} 56^{\prime} 38^{\prime \prime}$ & $113^{\circ} 44^{\prime} 26^{\prime \prime}$ & R200-48 & At RM 258 below Triumphal Arch \\
\hline 09404245 & $36^{\circ} 02^{\prime} 56^{\prime \prime}$ & $113^{\circ} 48^{\circ} 48^{\prime \prime}$ & R200-49 & At RM 267 below Bat Cave \\
\hline
\end{tabular}


Lake Mead that were collected from 1990 to 1994 and a description of electronic-data files. A description of the file format, selected hydrographic comparisons, and site-location maps are included in this report. The report also describes the submersible pressure transducers used to sense river stage and the process by which data were verified by periodic comparisons to fixed reference points related to arbitrary datum and presents selected data graphically. Not all instruments functioned throughout the entire data-collection period, and questionable data are not included in the final data set.

\section{Physical Setting}

The study area is on the Colorado River $4.5 \mathrm{mi}$ downstream from Glen Canyon Dam to upper Lake Mead, a distance of 305 river miles, and includes Grand Canyon National Park and a small part of Glen Canyon National Recreational Area in northern Arizona (fig. 1). The Colorado River originates in Colorado and has a total drainage area of about $250,000 \mathrm{mi}^{2}$. The river extends about $1,400 \mathrm{mi}$ through portions of five States from its headwaters to the Gulf of California and is impounded by 13 major reservoirs. Lake Powell and Lake Mead, two of the reservoirs, are at the upstream and downstream ends, respectively, of the study area. Glen Canyon Dam controls the flow of the river through the study reach.

The study reach of the Colorado River flows through Glen Canyon, Marble Canyon, and Grand Canyon. In these canyons, the river cuts deeply into layered rock units of sandstone, shale, limestone, schist, and gneiss that control the large-scale channel geometry (Dolan and others, 1978; Schmidt and Graf, 1990). In the study reach, the river flows through a series of pools, riffles, and rapids caused by talus deposits and debris flows from tributary canyons that formed constrictions in the river channel. The average water-surface gradient is 0.0015 between Lees Ferry and Diamond Creek and ranges from less than 0.0005 in pools to greater than 0.01 in rapids (Schmidt and Graf, 1990). The river can be characterized by hydraulic and sedimentary properties and classified into eleven reaches. The mean depths in these reaches range from 14.7 to $29.6 \mathrm{ft}$, and average widths range from 180 to $350 \mathrm{ft}$ (Graf and others, 1989). Cross sections at the stage-gaging sites range from about 75 to $420 \mathrm{ft}$ in width and 20 to 60 $\mathrm{ft}$ in maximum depths (fig. 2).

\section{River-Stage Conditions}

Glen Canyon Dam, which is designed and operated for flow regulation, water storage and delivery, and power generation, has been used to regulate flows from 1,000 to $33,200 \mathrm{ft}^{3} / \mathrm{s}$ for power production on any given day. Daily releases from the powerplant produce discharge waves in the river that are about $125 \mathrm{mi}$ long (Wiele and Smith, 1996) and produce changes of as much as $15 \mathrm{ft}$ in river stage (fig. 3). Downstream movement of the discharge wave produces smaller stage fluctuations because of the reduction of peak discharge and an increase in the trough discharge (Wiele and Smith, 1996). During this study, discharges in the river at the Lees Ferry gaging station ranged from about 1,800 to $29,500 \mathrm{ft}^{3} / \mathrm{s}$.

Research flows, designed and recommended by GCES scientists, were scheduled during 1990 and 1991 (fig. 4). Recorded flows at the streamflow-gaging station, Colorado River at Lees Ferry (fig. 5), differ only slightly from the scheduled flows. For example, flow on June 1,1991 , dropped to about $4,000 \mathrm{ft}^{3} / \mathrm{s}$ during a $5,000 \mathrm{ft}^{3} / \mathrm{s}$ steady-release research flow.

During this study, the effects of storm runoff from tributary canyons to the Colorado River were documented by stage gages upstream and downstream from such canyons. An increased stage at the stage-gaging station downstream from the Little Colorado River compared to a stage at a stage-gaging station upstream from the Little Colorado River represents inflow from winter storms in January 1993 (fig. 6). The comparison of river stage at R200-13 (river mile 55) and R200-15 (river mile 70) shows the response of the Colorado River stage to inflow of water and debris flow from ungaged tributary canyons on August 20 and 21, 1993 (fig. 7). The influence of flow from other tributary canyons on the Colorado River also is indicated by the stage-gage records above and below Bright Angel Creek and above and below Havasu Creek (figs. 8 and 9). 

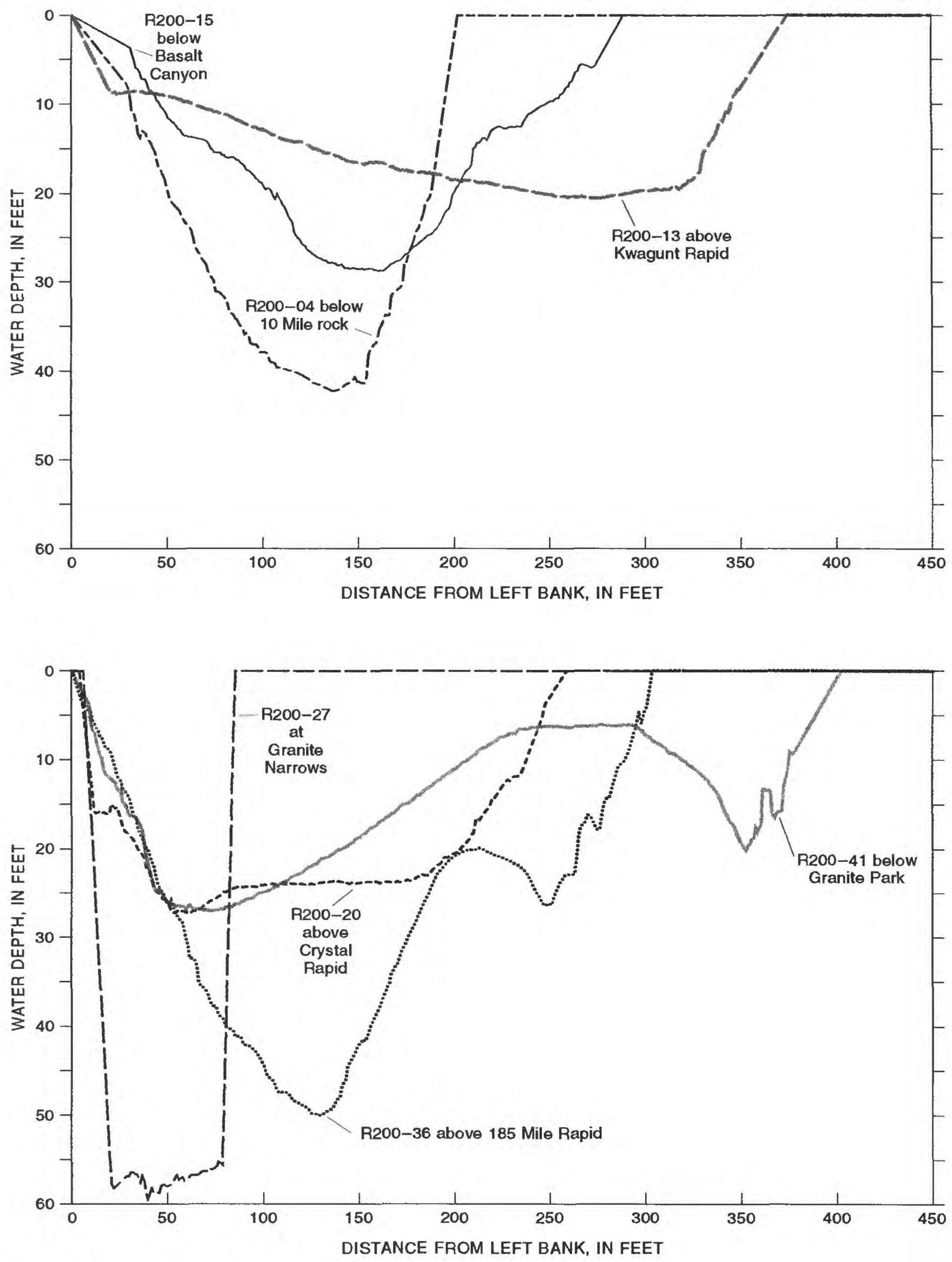

Figure 2. Cross sections at selected stage-gaging stations. 


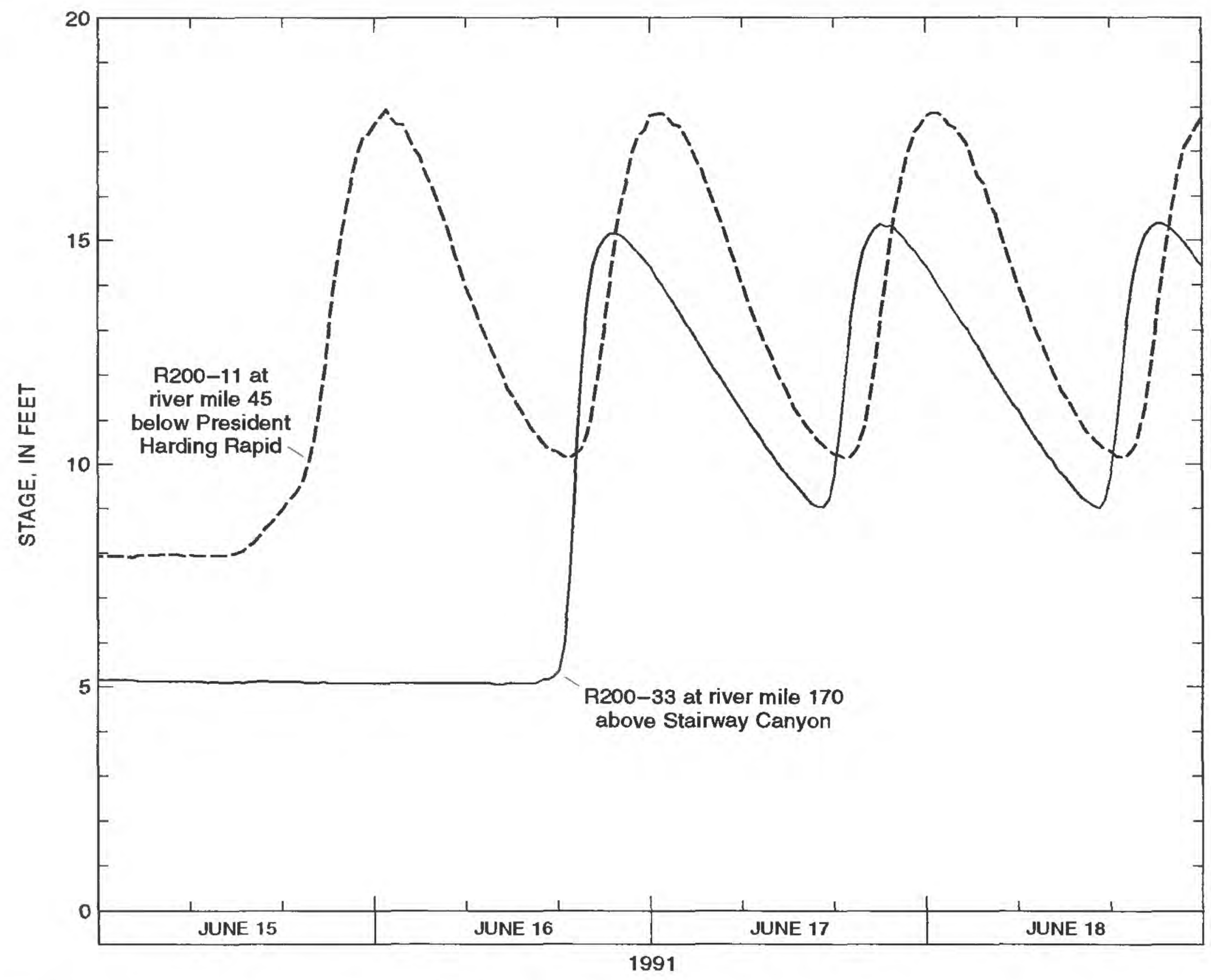

Figure 3. Stage of Colorado River at river miles 45 and 170.

\section{Acknowledgments}

Raft support for access to stage-gaging stations was provided by O.A.R.S., Inc. Field assistance was contributed by volunteers working under the USGS Volunteer For Science Program and included George Aukon, Morgan Brunstrom, Thomas Carter, Kathaleen Copper, Clarence Dunbar, David Gauger, Josh Gauger, William Gauger, James Heidt, Michael Hoffman, Phillip Lampear, Gary Lorinser, Keith Marroquin, Garvin Muri, Joe Pecor, William Perry, Nancy Ryan, Ervin Schmidt, and Adrian Sparks. Technical or field assistance was provided by the following USGS personnel: Nancy Brian, Jeff Coleman, Curt Crouch, Julia Graf, Greg Fisk, Lisa Ham, Robert
Hart, Sam Jansen, Roy Johnson, Greg Littin, Chris McIntosh, Ed Parrozzo, Carl Scott, J. Dungan Smith, John Sottilare, Nigel Sparks, and Adam Whitman.

\section{METHODS}

\section{Instrumentation}

Records of river stage were collected using two data recorders, one of which was an R200 data recorder (Johnson and Rorabaugh, 1988) that was used from June 1990 through July 1992. In the early stages of data collection, the minimum 


\section{UNSTEADY RELEASES}

(Each of the unsteady releases is preceded and followed by a steady flow of 5,000 cubic feet pet second: for 3 deys)

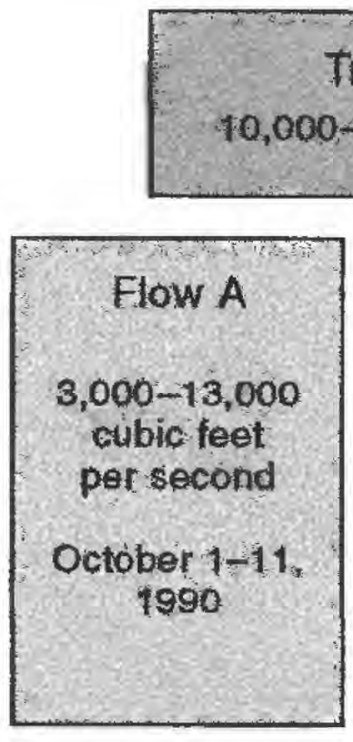

Trough to Peak Range $0,000-12,000$ cubic feet per second

Flow A
$000-13,000$
cubic feet
per second
ctober $1-11$.
1990
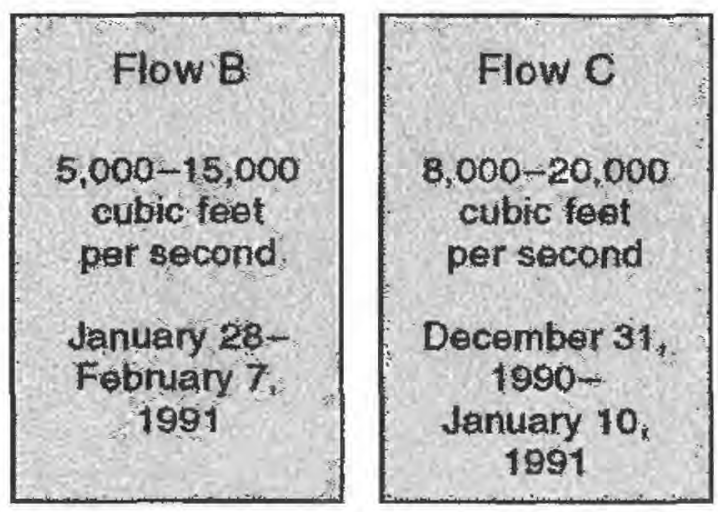

\section{Trough to Peak Range}

$20,000-23,200$ cubic feet per second

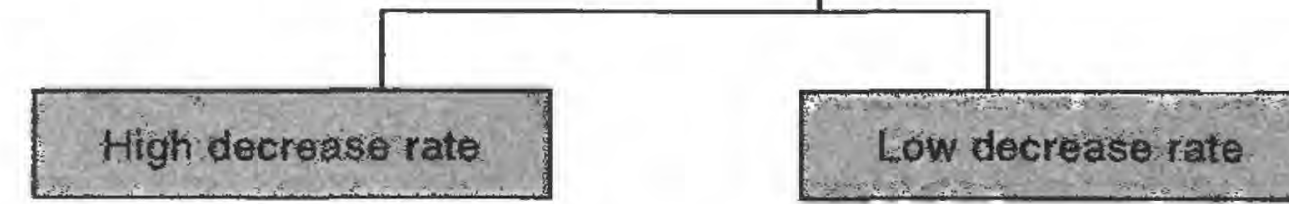

\begin{tabular}{|c|}
\hline Flow D \\
$3,000-26,000$ \\
cubic feet \\
per second \\
Low increase rate \\
May $6-16$ \\
1991
\end{tabular}
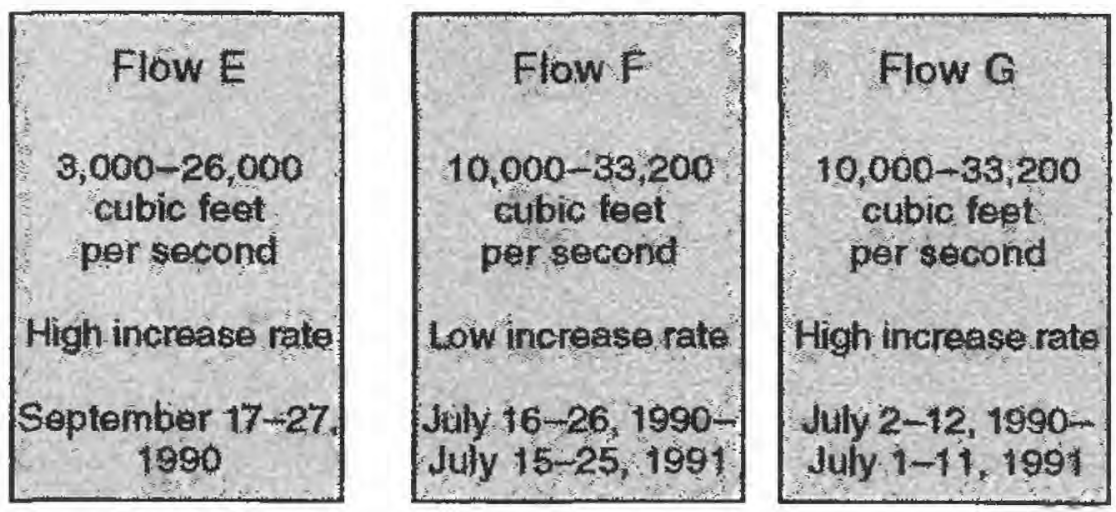

\section{STEADY RELEASES}

(Each of the steady releases is preceded and followed. by a steedy flow of 5,000 cubic feet per second for 3 days)
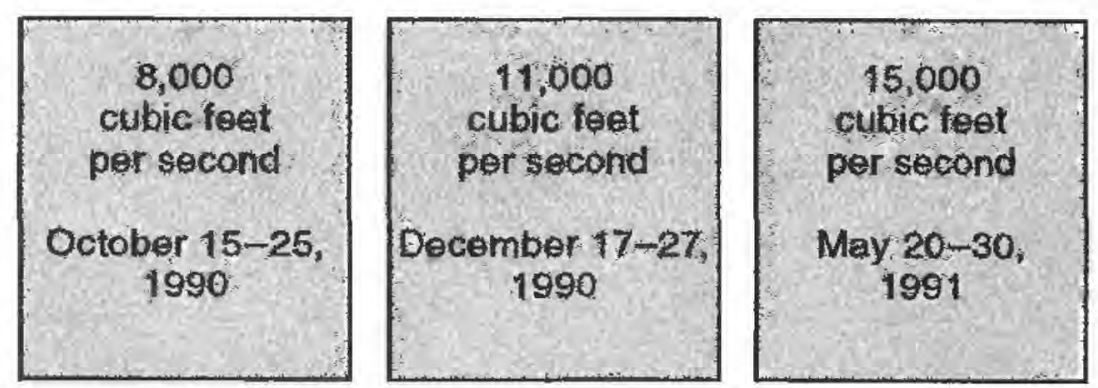

Figure 4. Research flows, June 1990 to July 1991. 

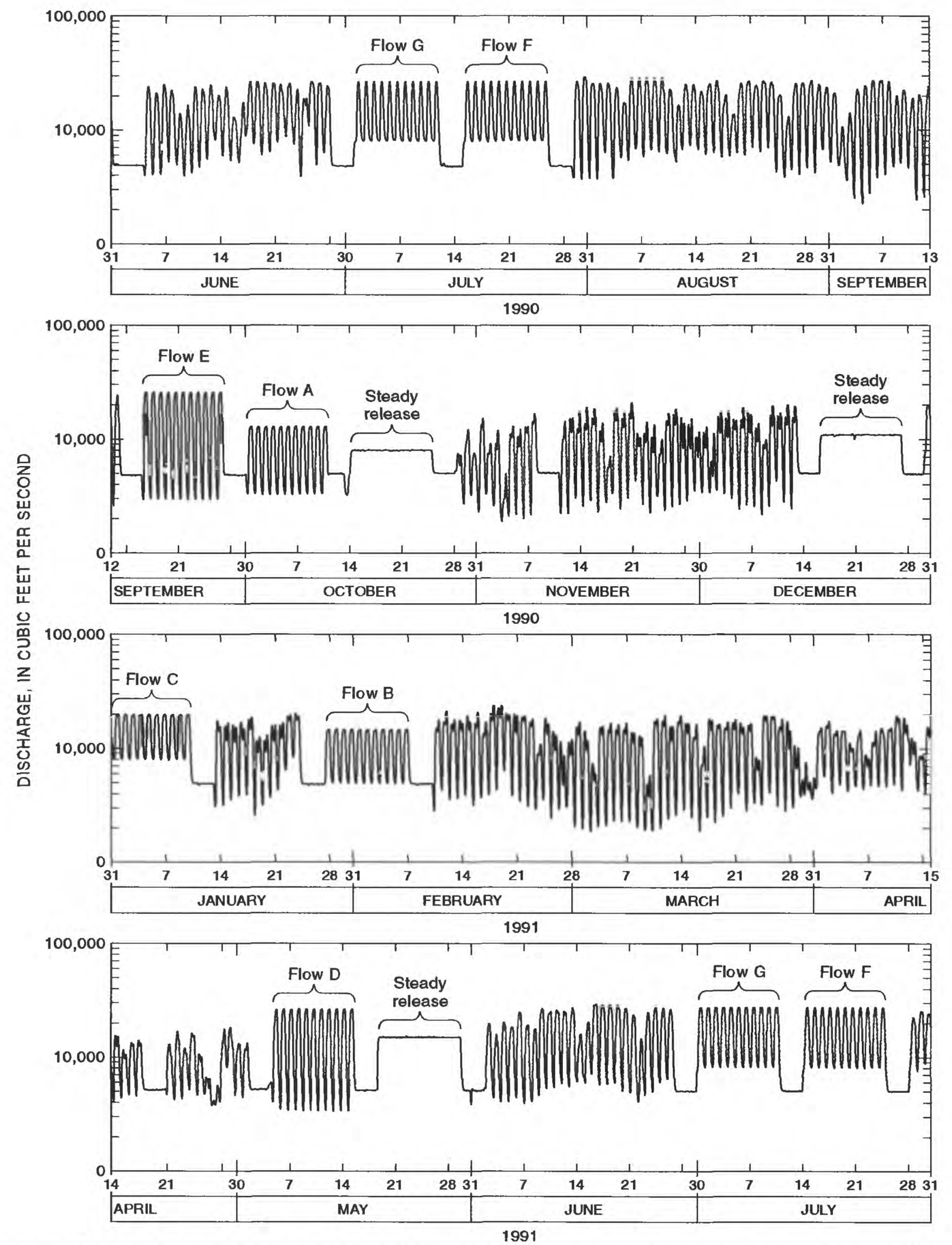

Figure 5. Discharges at streamflow-gaging station, Colorado River at Lees Ferry, Arizona, during researchflow period $1990-91$. 


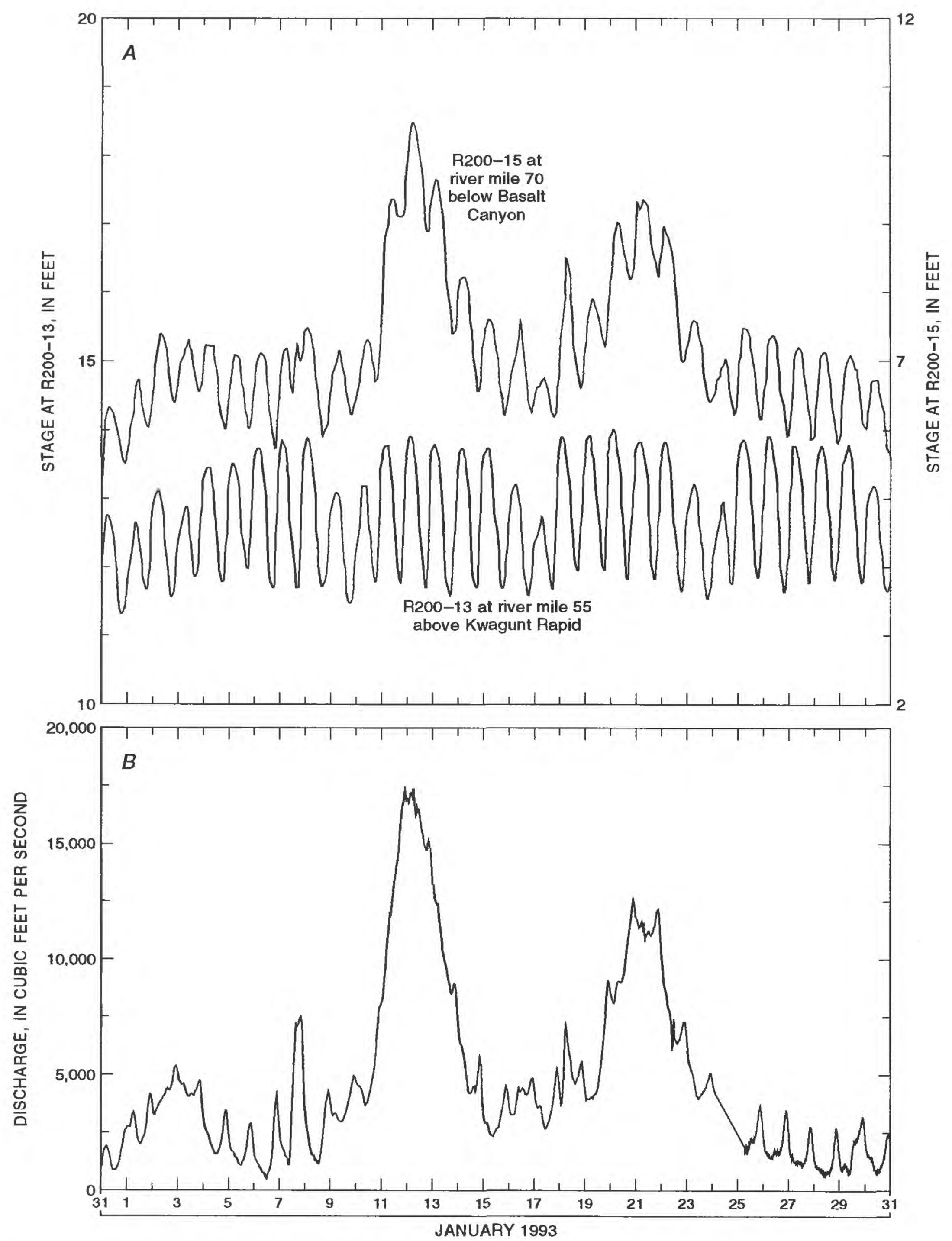

Figure 6. Comparison of stage of Colorado River at river miles 55 and 70 to inflow from the Little Colorado River at river mile 61.5. January 1993. A, Stage at river miles 55 and 70. B, Inflow from the Little Colorado River (Wiele and others, 1996). 


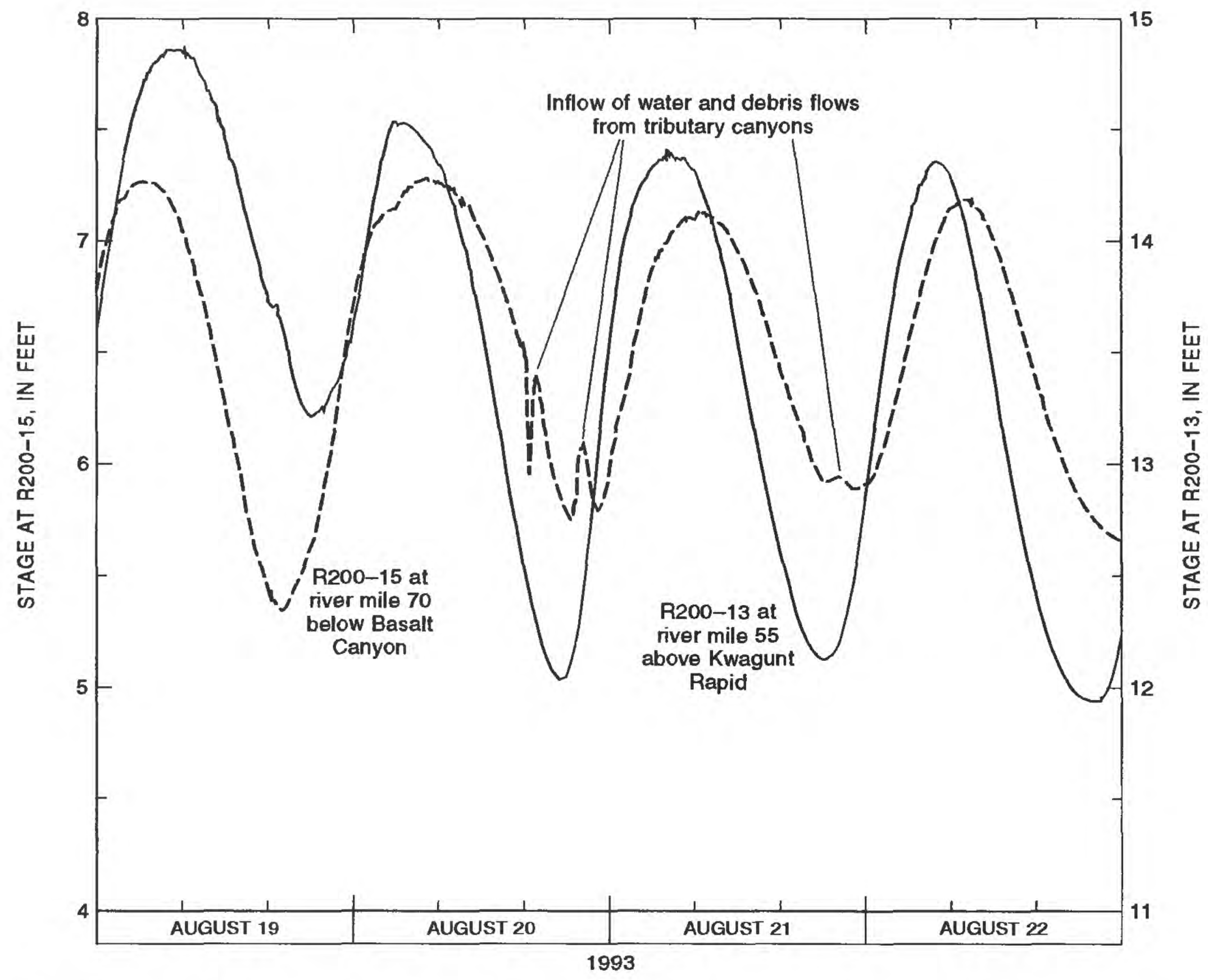

Figure 7. Comparison of stage of Colorado River at river miles 55 and 70 to show the response of stage to inflow of water and debris flows from ungaged tributary canyons, August 1993 (R.H. Webb, hydrologist, USGS, oral commun., 1996).

15-minute recording interval of the R200 was not adequate to define the stage wave during abrupt changes in stage (J.D. Smith, hydrologist, USGS, oral commun., 1991). Another recorder, Campbell Scientific, Inc., Basic Data Recorder (BDR) Model 301 programmed with a 5-minute recording interval, was equipped with a Druck Inc., Model PDCR 940 submersible pressure transducer and was used from 1991 to 1994 . The data-collection sites and instrumentation used in this study were designed for minimal disturbance to the setting of Grand Canyon National Park. Cables and recording instruments were hidden from view by a cover of rocks.

The R200 (fig. 10) was developed by the USGS for use in ground-water wells and was adapted for use in riverine environments for this study. The R200 is a battery-powered, microprocessor-controlled stage sensor and recorder and has two sections-a pressure transducer with electronics in the probe section and the battery holder. The pressure transducer in the probe section is the stage sensor that has an operating range of $35 \mathrm{ft}$ of river stage. This submersible transducer senses the pressure of the water above it relative to atmospheric pressure through a pressure port on the probe section. The transducer is vented so that changes in atmospheric pressure do not cause the R200 to record atmospheric changes as stage changes. A reference port on the pressure transducer is vented to the atmosphere through the vented probe, cable, and 

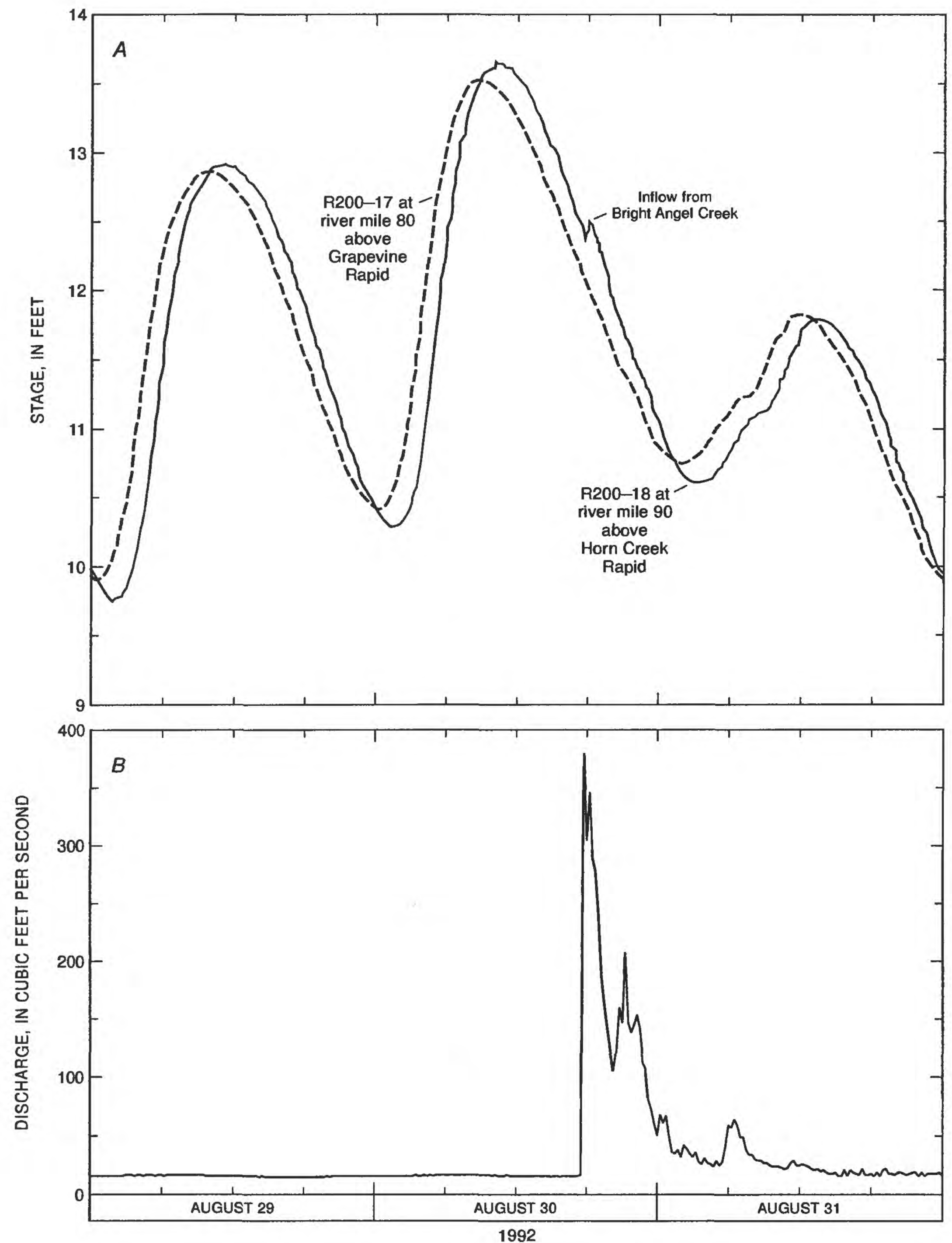

Figure 8. Comparison of stage of Colorado River at river miles 80 and 90 to inflow from Bright Angel Creek at river mile 88, August 1992. A, Stage at river miles 80 and 90 . B, Inflow from Bright Angel Creek. 

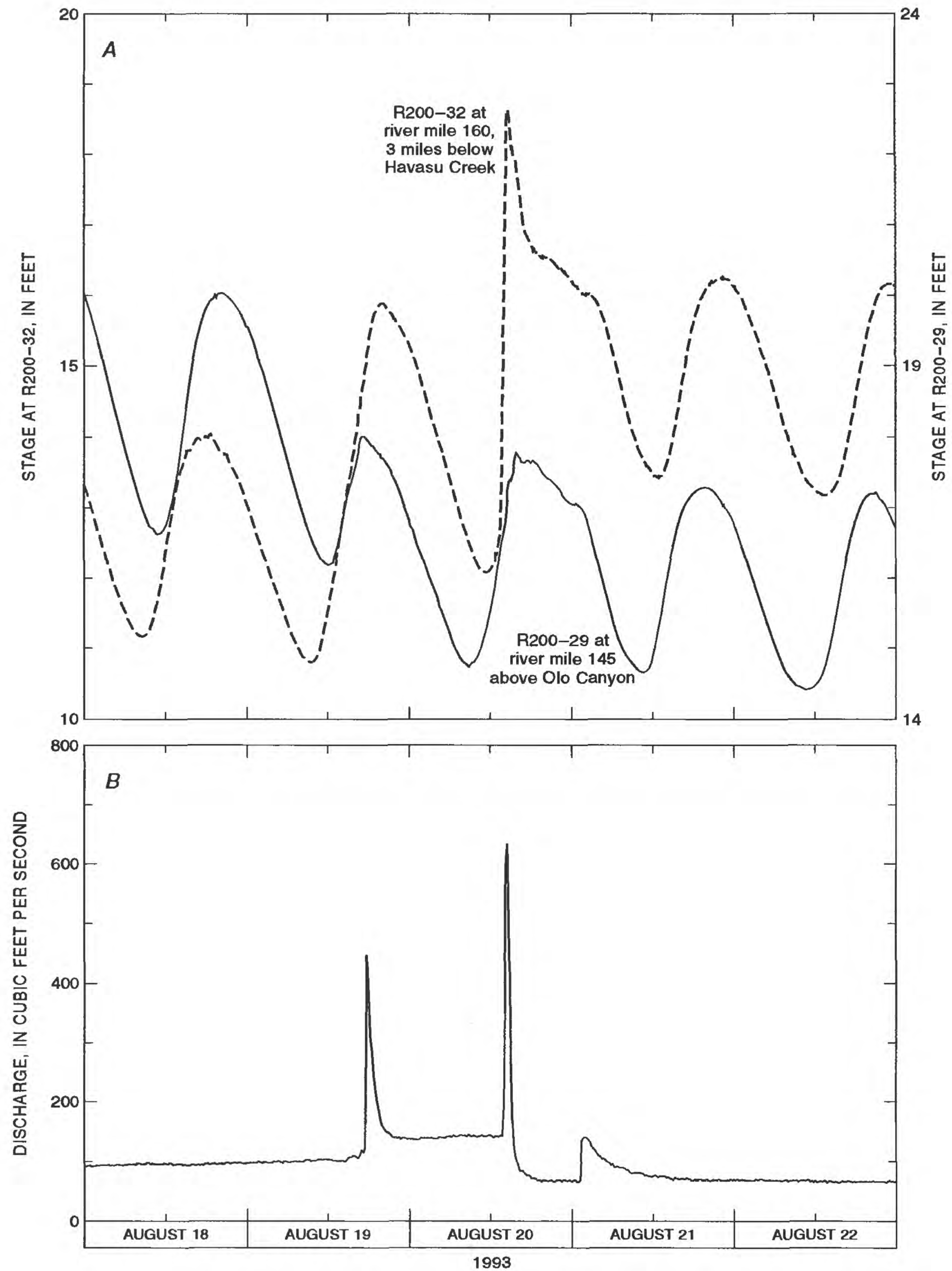

Figure 9. Comparison of stage of Colorado River at river miles 145 and 160 to inflow from Havasu Creek at river mile 157, August 1993. A, Stage at river miles 145 and 160. B, Inflow from Havasu Creek. 


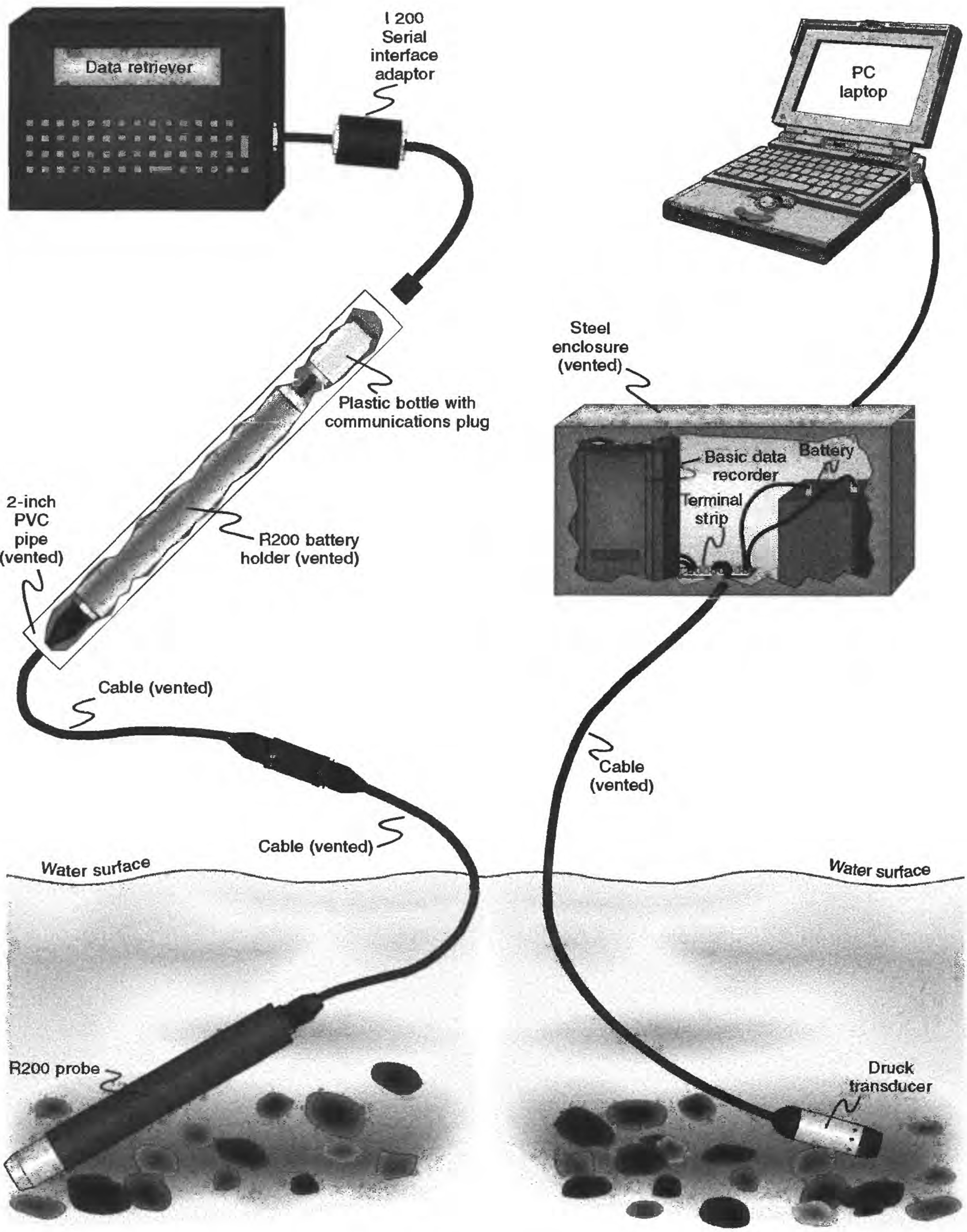

Figure 10. The R200 and the BDR data recorders. 
battery holder. For data collected in this study, a piece of filter fabric was secured over the pressure port to prevent sand from entering and blocking the transfer of water pressure to the transducer. The battery holder, which must remain dry, was placed above the anticipated high-water line. At the top of the battery holder, a communications plug is used to connect the R200 to a microcomputer. The microcomputer is used to input calibration data and to extract recorded data at the end of the recording period. During the data-collection period (1990-91), the R200 sensed and recorded the stage at 15 - or 30 -minute intervals (depending on the version of software in the R200). The R200 was deployed in the river by attaching it to a 1/4-inch steel cable secured to a 65-pound cast-iron anchor. The anchor, R200, and cable were lowered to a firm spot on the streambed by rope, and the steel cable was secured to an eyebolt set in rock on the river bank. The R200 cable was routed through the rocks on shore and the battery holder and communications plug were covered by rock above the expected high-water line (fig. 11). Along with the eyebolt, two other bolts were secured in rock at different elevations to be used as reference points for direct measurements of the water surface for stage verification.
The BDR (fig. 10), is a microprocessor-based electronic-data logging device. For this study, the $\mathrm{BDR}$ was programmed to sense and record data from a submersible pressure transducer that had an operating range of $35 \mathrm{ft}$ of river stage. As with the $\mathrm{R} 200$, the transducer was vented to the atmosphere through the cable to eliminate effects of changes in atmospheric pressure. The datalogger, batteries, and terminating end of the transducer cable were housed inside an atmospherically vented steel enclosure with moisture-absorbing desiccant packets (fig. 10). The enclosure and recording portion of the system were placed above the anticipated high-water line. The pressure transducer was covered with a filter fabric to prevent sand from entering and blocking the transfer of water pressure to the transducer. The BDR initially was programmed to record a value every 5 minutes and later was changed to record every 15 minutes. The 5 -minute values were the average of 5 averages of 10 readings made at 1-minute intervals. For the 15-minute recording interval, the average was computed from 5 averages of 10 readings made at 3 -minute intervals. The transducer used with the BDR was deployed using scuba equipment and was attached to the steel cable next to the R200 without

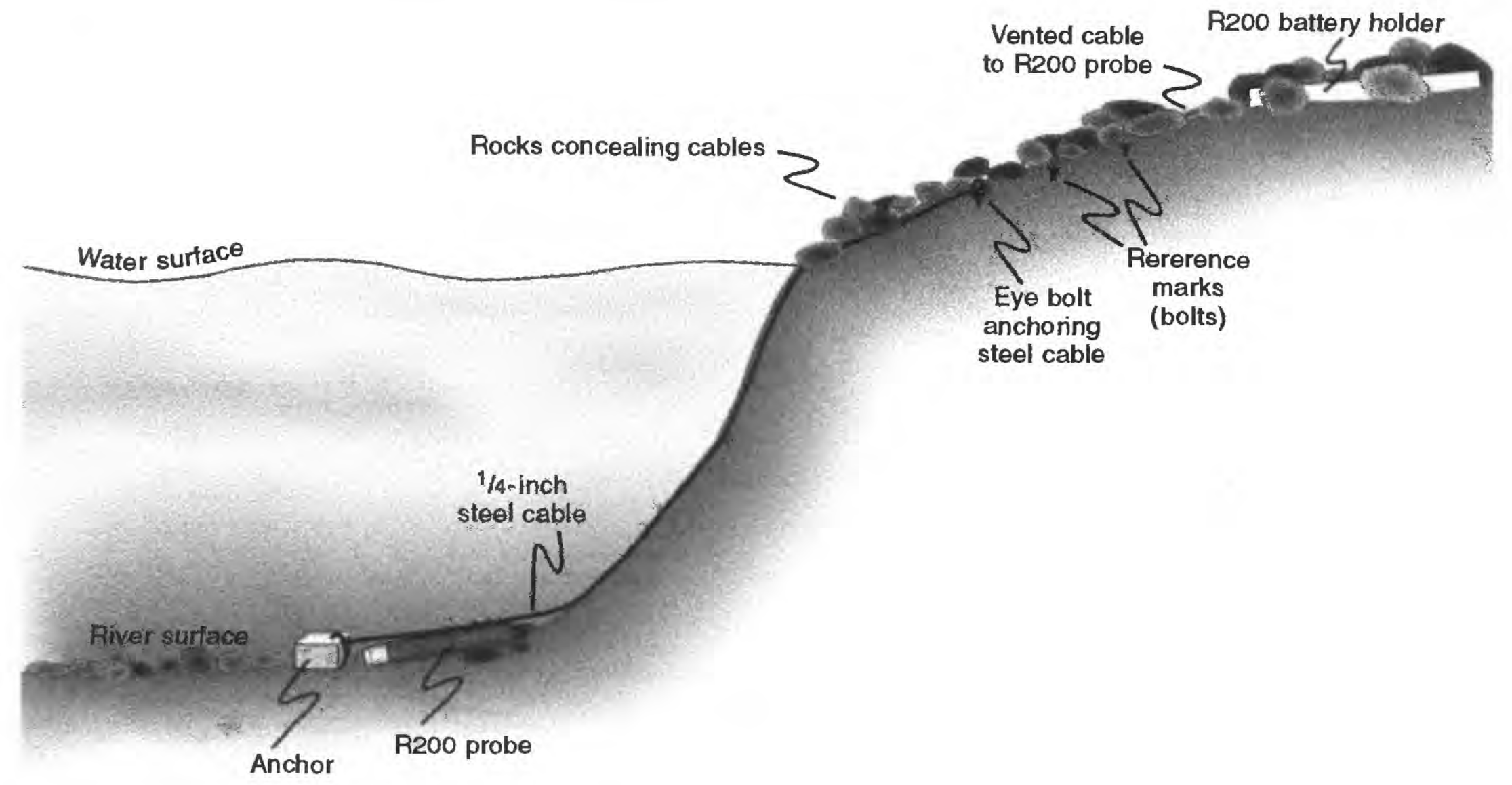

Figure 11. Typical transducer installation. 
disturbing the initial installation. The cables were placed next to the R200 cables, and the enclosure for the datalogger and batteries was placed next to the R200 battery holder and covered by rock.

\section{Data Retrieval}

R200 data were retrieved approximately every 6 weeks. BDR data were retrieved approximately every 3 months. In January 1994, the BDR recording interval was changed to 15 minutes, and the stations were not visited again until July 1994. During a site visit, the recorded stage was compared to a direct measurement of the water surface relative to reference points (bolts set in rock). Data stored since the last visit were downloaded onto a portable computer. Before leaving the site, new batteries were installed, and the recorded stage again was compared to a direct measurement of stage. Data retrieval and stage verification were documented in field notes.

\section{Station-Numbering System}

Forty-nine sites initially were established at about 5-river-mile intervals. A station identifier, such as R200-16, was assigned to each site as the sites were sequentially numbered in the downstream direction from 1 to 49 . R200 simply relates to the recording device first used in the project. Site number 14 at river mile 65 did not provide any reliable data because of vandalism and is not included in this report. During the data-collection period, 5 additional sites were installed between original sites bringing the total to 53 sites. These new sites were named by adding a sequential alpha character to the nearest upstream site. This identifier, such as R200-18A, denotes that the site is between sites R200-18 and R200-19. Also, site R200-18B would denote a site downstream from R200-18A and upstream from site R200-19. Each site then was assigned a USGS downstream-order number (Smith and others, 1994). The complete station name includes the USGS downstream-order number, the station identifier, an approximate distance in river miles downstream from Lees Ferry (Stevens, 1990), and a nearby landmark (table 1). For example, USGS station number 09402430 is R200 number 16 (R200-16) at river mile 76 above Hance Rapid.

\section{Records of Stage}

Arbitrary elevations were assigned to reference points at each site at the time the stage-gaging stations were installed. The same reference points also were used for the BDR network. Elevations as recorded by stage gages are not referenced to sea level. Stations upstream and downstream from Granite Rapid, Hermit Rapid, and Crystal Rapid use the same reference datum between upstream and downstream stations, and the difference in the stage between the two gages represents fall through each of these rapids (fig. 12). For the other sites, overall variability in the river-channel characteristics does not allow for direct comparisons of the stage data from one site to another (S.M. Wiele and J.D. Smith, hydrologists, USGS, written commun., 1991).

Stage data retrieved from the dataloggers were transferred to a USGS data base on the Arizona District computer. Corrections to stage data as indicated by periodic comparisons to reference points were used to correct for drift or movement of the transducers. Accuracy of records is limited by river surge, instrument drift, and accuracy of the transducers. Data in this report generally are accurate to $\pm 0.1 \mathrm{ft}$.

Records of stage at continuous-record streamflow-gaging stations also were used in verifying the stage data. Sites used are: 09379910 Colorado River below Glen Canyon Dam, Arizona; 09380000 Colorado River at Lees Ferry, Arizona; 09383100 Colorado River above the Little Colorado River, near Desert View, Arizona; 09402500 Colorado River near Grand Canyon, Arizona; 09404120 Colorado River above National Canyon, near Supai, Arizona; and 09404200 Colorado River above Diamond Creek, near Peach Springs, Arizona.

\section{ACCESS TO DATA}

Available data (fig. 13) will be provided electronically, upon request, in standard B-card format (table 2). Data files are named in the form: 


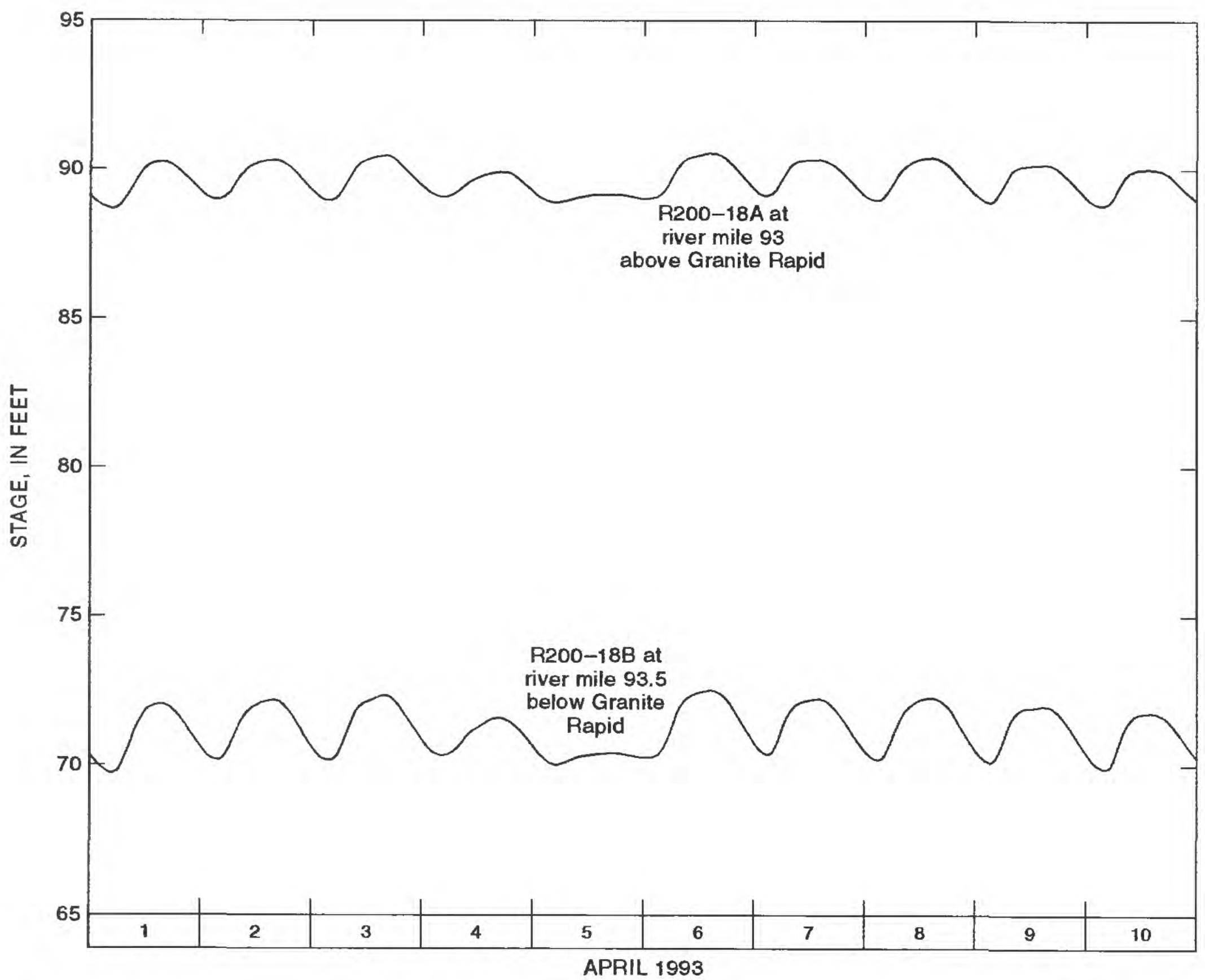

Figure 12. Comparison of stage of Colorado River upstream and downstream from Granite Rapid.

b9383009 and r9383009, where the alpha character designates the recording device, $b$ for BDR and $r$ for R200 and the numerical sequence is the USGS downstream-order number (table 1) without the leading 0 . The first line in each data file is the "2" card and states the following site-specific information.

\begin{tabular}{cl}
\hline Column & \multicolumn{1}{c}{ Description } \\
\hline 1 & Card type (2). \\
$2-16$ & USGS downstream-order number (table 1). \\
$29-33$ & Parameter code (00065, gage height). \\
$34-38$ & Statistic code (00011, instantaneous). \\
The second line and all succeeding lines in each data file are B cards \\
and contain the following information. \\
1 & Card type (B). \\
$2-16$ & USGS downstream-order number (table 1). \\
\hline
\end{tabular}

\begin{tabular}{cl}
\hline Column & \multicolumn{1}{c}{ Description } \\
\hline $17-20$ & $\begin{array}{l}\text { Four-digit calendar year in which the observa- } \\
\text { tion was made. } \\
\text { Two-digit month in which the observation was } \\
\text { made. } \\
\text { Two-digit day in which the observation was } \\
\text { made. } \\
\text { Time, 6-digit time as HHMMS (HH. hour in } \\
23-24\end{array}$ \\
$25-30$ & $\begin{array}{l}\text { 24-hour system, MM as minute, and SS as } \\
\text { seconds). } \\
\text { Total minutes in the day (1440). } \\
\text { River stage, in feet. }\end{array}$ \\
\end{tabular}

\section{SELECTED REFERENCES}

Bureau of Reclamation, 1988, Glen Canyon Environmental Studies - Final report: Bureau of Reclamation report, $86 \mathrm{p}$. 
Table 2. Sample data table in standard B-card format
209383009
B 09383009
B 09383009
B 09383009
B 09383009
B 09383009
B 09383009
B 09383009
B 09383009
B 09383009
B 09383009
B 09383009
B 09383009
B 09383009
B 09383009
B 09383009
B 09383009
B 09383009
B 09383009
B 09383009
B 09383009
B 09383009
B 09383009
B 09383009
B 09383009
B 09383009
B 09383009
B 09383009
B 09383009
B 09383009
B 09383009
B 09383009
B 09383009
B 09383009
B 09383009
B 09383009
B 09383009
B 09383009
B 09383009
B 09383009
B 09383009
B 09383009
B 09383009
B 09383009
B 09383009
B 09383009
B 09383009
B 09383009
B 09383009
B 09383009
B 09383009
B 09383009

0006500011

$\begin{array}{lll}19901111130000 & 1440 & 7.72 \\ 19901111133000 & 1440 & 7.75 \\ 19901111140000 & 1440 & 7.75 \\ 19901111143000 & 1440 & 7.75 \\ 19901111150000 & 1440 & 7.75 \\ 19901111153000 & 1440 & 7.75 \\ 19901111160000 & 1440 & 7.72 \\ 19901111163000 & 1440 & 7.72 \\ 19901111170000 & 1440 & 7.72 \\ 19901111173000 & 1440 & 7.69 \\ 19901111180000 & 1440 & 7.69 \\ 19901111183000 & 1440 & 7.69 \\ 19901111190000 & 1440 & 7.69 \\ 19901111193000 & 1440 & 7.69 \\ 19901111200000 & 1440 & 7.69 \\ 19901111203000 & 1440 & 7.69 \\ 19901111210000 & 1440 & 7.72 \\ 19901111213000 & 1440 & 7.72 \\ 19901111220000 & 1440 & 7.72 \\ 19901111223000 & 1440 & 7.72 \\ 19901111230000 & 1440 & 7.69 \\ 19901111233000 & 1440 & 7.72 \\ 19901111240000 & 1440 & 7.72 \\ 19901112003000 & 1440 & 7.72 \\ 19901112010000 & 1440 & 7.75 \\ 19901112013000 & 1440 & 7.72 \\ 19901112020000 & 1440 & 7.75 \\ 19901112023000 & 1440 & 7.72 \\ 19901112030000 & 1440 & 7.72 \\ 19901112033000 & 1440 & 7.75 \\ 19901112040000 & 1440 & 7.75 \\ 19901112043000 & 1440 & 7.72 \\ 19901112050000 & 1440 & 7.72 \\ 19901112053000 & 1440 & 7.67 \\ 19901112060000 & 1440 & 7.58 \\ 19901112063000 & 1440 & 7.48 \\ 19901112070000 & 1440 & 7.35 \\ 19901112073000 & 1440 & 7.15 \\ 19901112080000 & 1440 & 6.93 \\ 19901112083000 & 1440 & 6.66 \\ 19901112090000 & 1440 & 6.44 \\ 19901112093000 & 1440 & 6.14 \\ 19901112100000 & 1440 & 5.92 \\ 19901112103000 & 1440 & 5.67 \\ 19901112110000 & 1440 & 5.43 \\ 19901112113000 & 1440 & 5.21 \\ 19901112120000 & 1440 & 5.10 \\ 1991112130000 & 1440 & 4.99 \\ 19.96 \\ 191133000 & 1440 & 4.99 \\ 190000 & 1440 & 5.21\end{array}$


STATION

IDENTIFIER

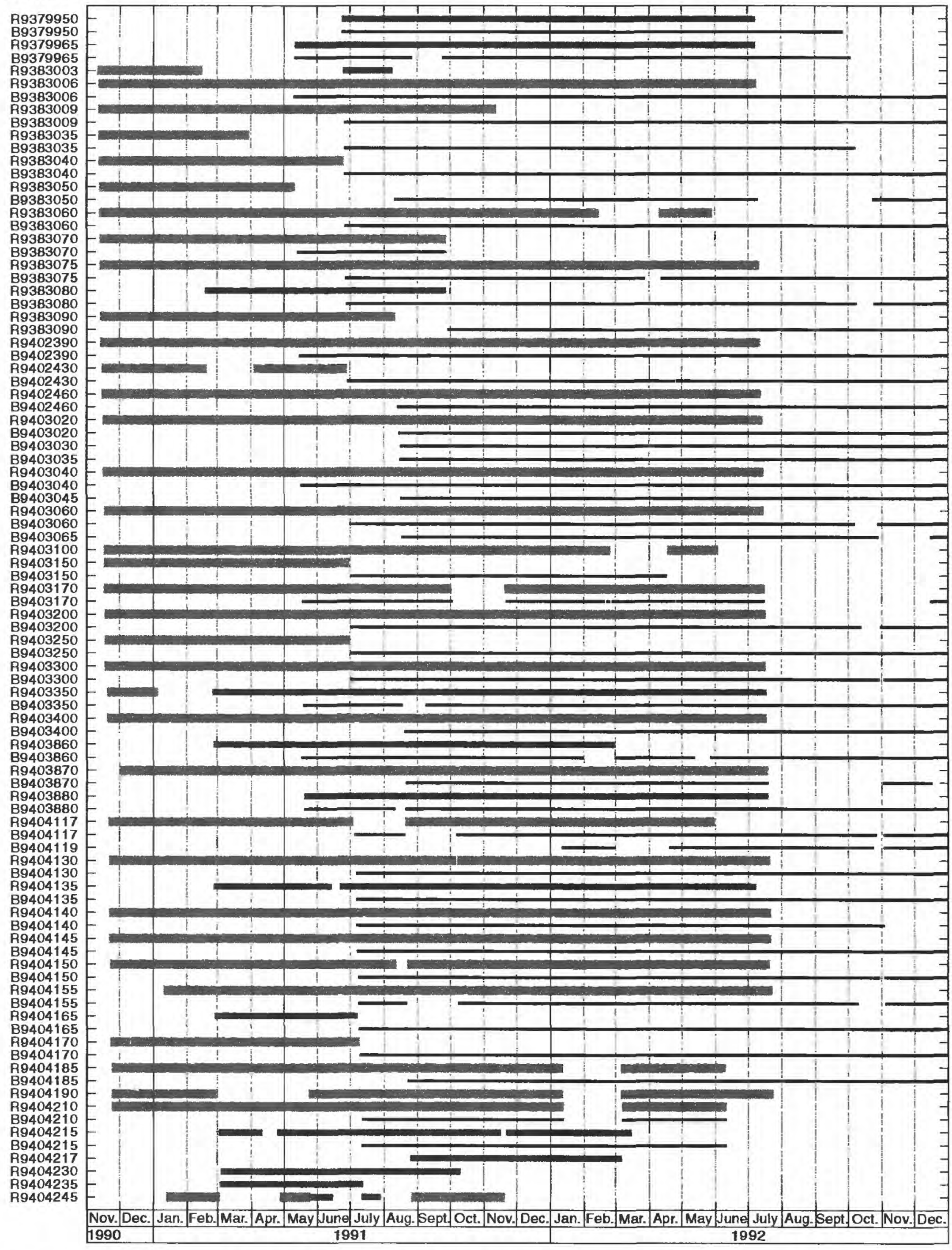

Figure 13. River-stage data, Colorado River, Glen Canyon Dam to upper Lake Mead, Arizona, November 1990 through July 1994. 
STATION

IDENTIFIER

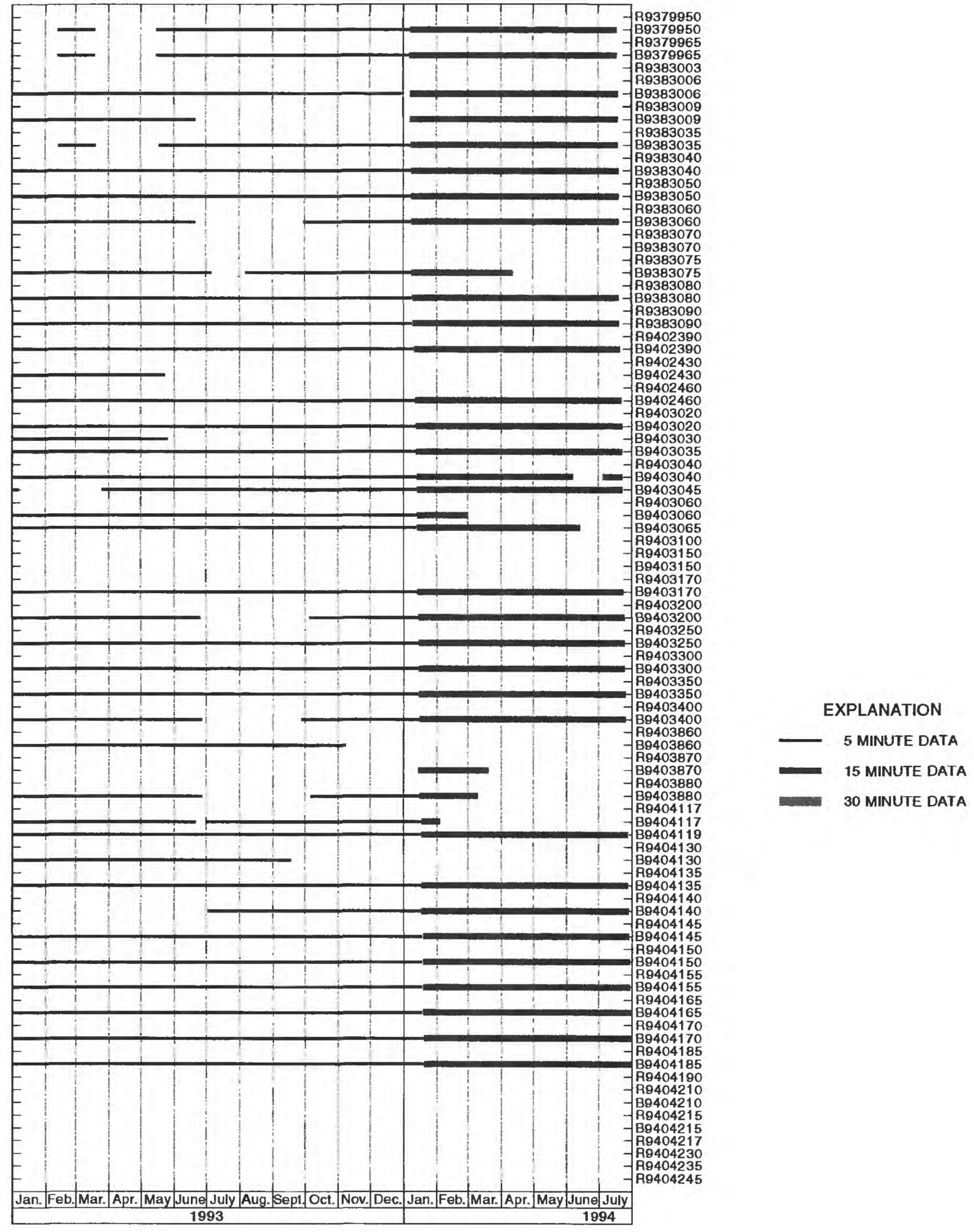

Figure 13. Continued. 
Dolan, Robert, Howard, Alan, and Trimble, David, 1978, Structural control of the rapids and pools of the Colorado River in Grand Canyon: Science, v. 202, p. 629-631.

Griffin, E.R., and Wiele, S.M., 1996, Calculated hydrographs at selected sites along the Colorado River downstream from Glen Canyon Dam: U.S. Geological Survey Water-Resources Investigations Report 95-4266, $30 \mathrm{p}$.

Graf, J.B., Schmidt, J.C., and Kieffer, S.W., 1989, Hydraulic log of the Colorado River from Lees Ferry to Diamond Creek, Arizona-Chapter 2, in Elston, D.P., Billingsley, G.H., and Young, R.A., eds., Geology of Grand Canyon, Northern Arizona: American Geophysical Union, Field Guide for the 28th International Geological Congress, Washington, D.C., July 1989, p. 37-47.

Johnson, R.A., and Rorabaugh, J.I., 1988, Operating manual for the R200 downhole recorder with Husky Hunter retriever: U.S. Geological Survey Open-File Report 88-455, $111 \mathrm{p}$.

National Research Council, 1987, River and dam management-A review of the Bureau of Reclamation's Glen Canyon Environmental Studies: Washington, D.C., National Academy Press, 203 p.
Schmidt, J.C., and Graf, J.B., 1990, Aggradation and degradation of alluvial sand deposits, 1965 to 1986, Colorado River, Grand Canyon National Park, Arizona: U.S. Geological Survey Professional Paper $1493,74 \mathrm{p}$.

Smith, C.F., Anning, D.W., Duet, N.R., Fisk. G.G., McCormack, H.F., Pope, G.L., Rigas, P.D., and Wallace, B.L., 1995, Water-resources data, Arizona, water year 1994: U.S. Geological Survey Water-Data Report AZ-94-1, p. 7-8.

Stevens, Larry, 1990, The Colorado River in Grand Canyon-A comprehensive guide to its natural and human history, 3rd ed.: Flagstaff, Arizona, Red Lake Books, 115 p.

Wiele, S.M., and Smith, J.D., 1996, A reach-averaged model of diurnal discharge wave propagation down the Colorado River through the Grand Canyon: American Geophysical Union, Water Resources Research, v. 32, no. 4, p. 1375-1386.

Wiele, S.M., Graf, J.B., and Smith, J.D., 1996, Sand deposition in the Colorado River in Grand Canyon from flooding of the Little Colorado River: American Geophysical Union, Water Resources Research, v. 32, no. 12, December 1996, p. 3579-3596. 